\title{
Characterization and estimation of gas-bearing properties of Devonian coals using well log data from five Illizi Basin wells (Algeria)
}

\author{
Rafik Baouche ${ }^{1}$, David A. Wood ${ }^{2 \oplus_{*}}$ \\ ${ }^{1}$ Department of Geophysics, Laboratory of Resources Minérals and Energétiques, Faculty of Hydrocarbons and Chemistry (FHC), \\ University M'Hamed Bougara Boumerdes, 35000 Boumerdès, Algeria \\ ${ }^{2}$ DWA Energy Limited, Lincoln, United Kingdom
}

\section{Keywords:}

Illizi Basin coals Algeria

coal-bed methane potential

Devonian coal seam areal trend

gas content estimates by modified Kim

equation

machine learning

Cited as:

Baouche, R., Wood, D.A.

Characterization and estimation of gas-bearing properties of Devonian coals using well $\log$ data from five Illizi Basin wells (Algeria). Advances in Geo-Energy Research, 2020, 4(4): 356-371, doi: 10.46690/ager.2020.04.03.

\begin{abstract}
:
In Algeria, wells drilled in the Illizi Basin suggest the presence of a significant areal trend of Devonian coal seams with the thickest coal seams penetrated in the Lower Devonian stratigraphic unit F6. This makes them some of the oldest thick coal seams encountered. These coals exist between approximately 1500 and 4000 meters below surface. In particular, numerous coals in these formations drilled in the Oudoume field have recorded gas shows while drilling. A study of basic well log data from five wells penetrating Illizi Basin coals is conducted to characterize their distribution and provisionally evaluate their gas-bearing potential using petrophysical analysis coupled with machine learning. A simple multi-layer perceptron model (one hidden layer with four nodes) is used in a novel way to replicate estimates of gas saturation in the coal samples calculated approximately with the modified Kim equation. It does so by considering three commonly measured well-log variables: gamma ray, sonic travel time, deep resistivity (307 data records from the five wells studied). The log-calculated approximations (modified Kim equation) can be matched to better than plus or minus $1 \mathrm{scf} /$ ton by the multi-layer perceptron model. The results and analysis presented provide preliminary encouragement that suggests the presence of a potentially extensive gas-bearing Devonian coal trend in the Illizi Basin that is worthy of further exploration. Future work is required to integrate data from additional wells and laboratory analysis of core samples to verify the extent of that coal trend and to quantify its gas concentrations.
\end{abstract}

\section{Introduction}

Australia, Canada, China, India and the United States of America (USA) are countries that produce significant quantities of coal-bed methane (CBM). The Energy Information Administration of the USA (EIA) reports proven CBM reserves for the U.S. of about 11.9 trillion cubic feet (tcf) and CBM production of about 980 bcf in 2017 (EIA, 2020), making it one of the most prolific CBM exploiting countries.

Coal is constituted by almost pure carbon, ash, moisture and gas with unique physical and chemical characteristics and well-log responses that are distinct from conventional reservoirs (Flores, 1998, 2013; Reddy, 2010). CBM is formed partly by biogenic processes at shallower depths and by the decomposition and catagenesis of the organic components within coals as they are buried more deeply and the coals thermally mature (Strapoć et al., 2011; Moore, 2012). CBM adheres to fracture and pore surfaces within the coal as it is gradually expelled from the coal matrix (Laxminarayana and Crosdale, 2002; Crosdale et al., 2008; Busch and Gensterblum, 2011). This means that CBM production methods differ substantially from those used to produce gas from highly porous conventional reservoirs (Ayers, 2002; Liu et al., 2011; Seidle, 2011).

Natural gas storage and flow within coal seams is complex partly because coal formations are for the most part tight formations (low in porosity and permeability) and because they

\section{Yandy
Scientific}

Press
${ }^{*}$ Corresponding author.

E-mail address: r_baouche@yahoo.fr (R. Baouche); dw@dwasolutions.com (D.A. Wood).

2207-9963 (c) The Author(s) 2020.

Received August 20, 2020; revised September 7, 2020; accepted September 7, 2020; available online September 12, 2020. 
typically demonstrate two distinct distributions of porosity (Levine, 1993; Liu et al., 2015) and three distinct fluid flow sequences which are hydrodynamically driven by the interactions of water and gas making up the formation fluids. These three flow processes begin with desorption of gas from within the coal matrix. This diffused gas then flows through the coal matrix porosity network until it reaches one of the intermittently spaced cleats or natural fractures. Once gas enters the cleat system it is transported by laminar flow through that cleat or natural facture system which in its natural state is filled mainly with water.

CBM can be effectively produced from sub-surface coal resources by reducing their pressure by pumping out the water from the cleat systems (Bodden and Erlich, 1998; Li et al., 2015). Typically, the water-saturated cleat systems of CBM formations need to have substantial quantities of water removed, and the depressurization phase takes substantial time, perhaps a year or more for each well bore (McLennan et al., 1995; Li et al., 2018). The induced decline in formation pressure, resulting over time from the water-pumping / depressurization process, stimulates natural gas desorption from the coal matrix. The gas desorption rate tends to increase substantially once the formation pressure falls lower than a certain threshold (Tang et al., 2017); that threshold varies from formation to formation depending on the pore-scale distribution and cleat spacing of the coal. It is at that point that gas flow into a CBM well bore overtakes the volume of water being pumped from it.

Gas stored in coal is quite distinct from the way gas is stored and distributed in conventional porous reservoirs (Diamond and Schatzel, 1998). Porous reservoirs are dominated by free gas filling the pore space and, in certain formations, partly in natural fractures. On the other hand, most gas stored within coal seams is adhered to its cleat and pore surfaces (Laxminarayana and Crosdale, 1999). The microporosity network distributed throughout the coal matrix consists of a huge surface area, despite the matrix porosity of coal typically being less than $2.5 \%$. Such a large surface area means that it is available for gas to adhere to. This results in low porosity coal seams being able to store substantially more gas in their microporous matrix, in an adhered state, than macroporous sandstone and carbonate conventional reservoirs. Their commercial appeal lies in that characteristic. Fracture stimulation has the potential to release substantial gas from a coal's microporous network (Lu et al., 2019), but not all coals release their gas easily (Olajossy and Cieślik, 2019).

Gas moves or flows within the coal matrix through the microporous network, primarily by diffusion. Rates of diffusion are determined by gas concentration gradients that evolve in the microporous network (Busch et al., 2006; Masterlerz et al., 2008). This can be modelled using diffusion theory and Fick's law to determine a diffusion coefficient (Pillalamarry et al., 2011). As gas enters the cleat (fracture) system of a coal seam, its flow tends to follow Darcy's law, as it would in conventional porous reservoirs. Coalbed methane reservoir characterization and production performance have been extensively studied and modelled in recent years (Pan and Wood, 2015). It is clear that certain reservoir parameters and adverse geomechanical shrinkage changes to the coal matrix during methane desorption can result in slow release of gas from coal seams (Olajossy, 2017).

The CBM production process therefore involves three distinct flow stages (Bustin and Clarkson, 1998; Clarkson and Bustin, 2000): (i) initially dominated by formation water pumped from the cleats; (ii) water with dispersed natural gas bubbles as the formation pressure declines; the gas is not present in sufficient quantities to form a distinct two-phase fluid; and, (iii) a two-phase fluid system eventually with gas exceeding water; the relative permeability of the formation to gas exceeds that of water during this final gas-depletion flow phase (Crosdale et al., 2008).

The dewatering phase of CBM production involves high operating costs associated with energy requirements and water handling. The water produced is not clean but typically contaminated with mineral salts and some heavy metals. This means that it must be treated and/or reinjected to adequately dispose of it in a safe and environmental manner. The cost of produced-water handling has a negative impact on the economic viability of most CBM projects. In agricultural regions the risks of soil contamination from $\mathrm{CBM}$-produced water need to be mitigated.

These distinctive features of coals and the extent to which they store and release the gas they contain require careful characterization in order to understand their potential as commercial sources of gas. This is particularly so for deeply buried coal sequences that are not easily available for near-surface sampling and analysis. Well-log data can help to characterize deep poorly explored coals and provide provisional analysis of their gas bearing potential as well as insight to their physical properties. This is the case with the Devonian coals of the Illizi Basin studied here with the aid of a machine learning model to relate well log variables to estimates of their gas content.

\section{Geological setting and energy industry implications}

The Illizi Basin (Fig. 1) has a surface area of 108,424 $\mathrm{km}^{2}$. It has been studied extensively since 1956 with the discovery of the large Edjeleh oil field in the Amenas district close to the border with Libya. Some 700 explorations and appraisal wells have been drilled in the basin with a discovery success rate of $23 \%$. This has resulted in ninety eight discoveries (54 oil and 44 gas fields). The significant field discoveries include Tin Fouyé, Zarzaitine, Edjeleh, Alrar, Ohanet, and Stah. The Oudoume field is located in the western part of the Illizi Basin (Fig. 1). Available well information identifies numerous methane-bearing coals are distributed within the Devonian formations present in the Oudoume field and some surrounding wellbores (Fig. 2). A well from this field (OU), together with four other wells (OIT, IH, SED and TZM), distributed across the north and central areas of the Illizi Basin, provide insight to the distribution and gas-bearing nature of the coals in this part of the basin.

The Illizi Basin was dominated through its depositional history by shallow marine conditions along a continental margin (Beuf et al., 1972; Eshard et al., 2005). Erosion of the 


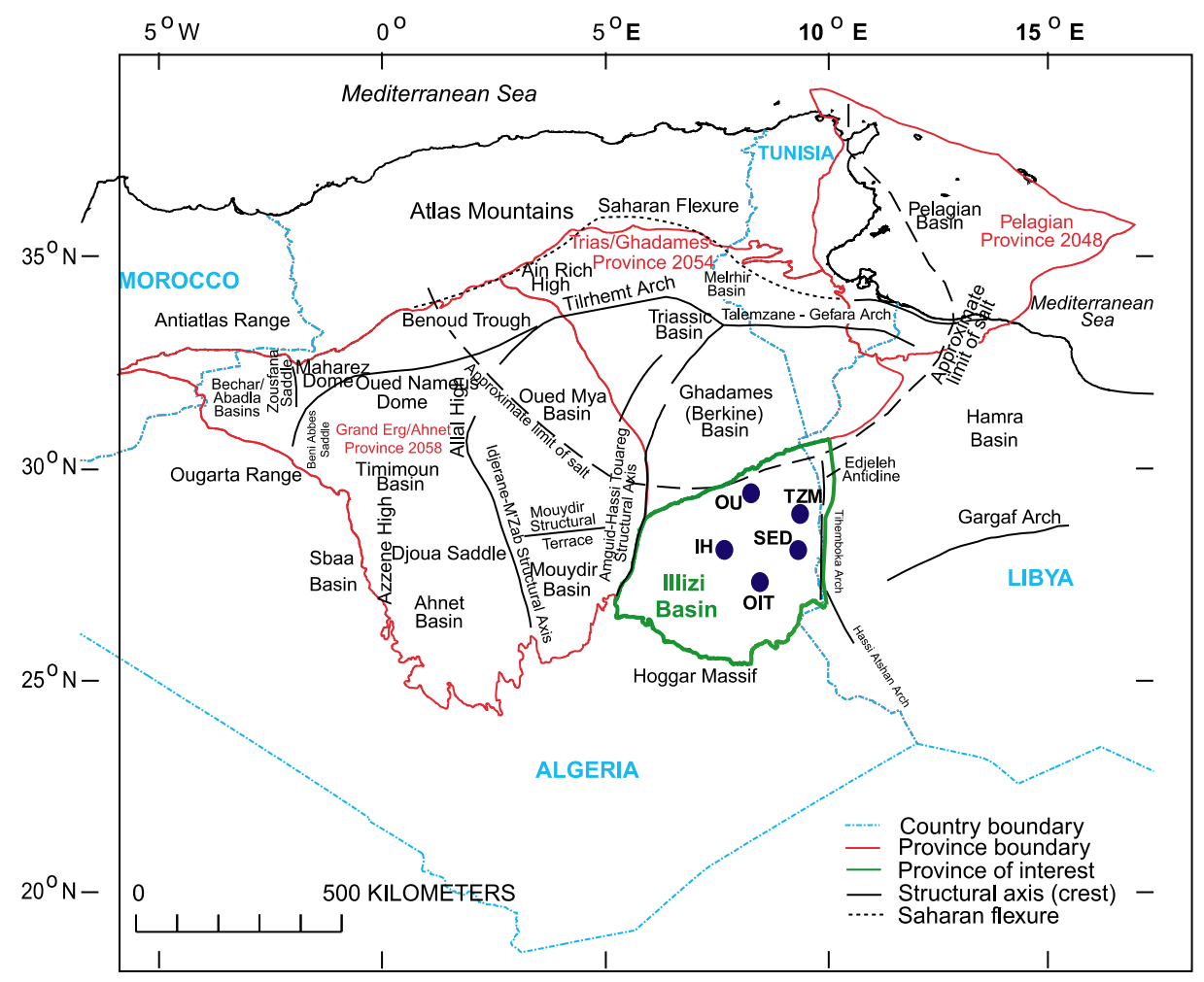

Fig. 1. Location of five studied wells used to establish the characteristics of Devonian coal seams in the north and central Illizi Basin, Algeria.

adjacent continent deposited a major Paleozoic sedimentary sequence that is overlain by Mesozoic sediments deposited above the regionally extensive and clearly distinguished Hercynian unconformity (Ghienne et al., 2007). The most important oil-bearing systems within the Illizi Basin include Cambro-Ordovician and Devonian reservoirs.

Reservoirs Unit II (Cambrian) has a mean thickness of $250 \mathrm{~m}$. It consists of fluvio-deltaic deposits (Fekirine and Abdallah, 1998) and produces oil in the West Ihansatene, East Tiguentourine, Ouan Taredert and Collenias anticlines. Reservoir Unit III-2 (Ordovician), consists of fine to coarse quartzitic sandstones with thicknesses varying from 0 to 200 m (Boote et al., 1998; Le Heron et al., 2009). This reservoir produces through fractured zones in the Hassi Tabtab and Assekaifaf fields. Reservoir Unit IV (Ordovician) consists of fluvio-glacial to periglacial deposits with thickness varying from 10 to $350 \mathrm{~m}$ (Hirst, 2012). Although there are thin coallike seams present in the Ordovician Unit IV of well TZM, the coal seams are primarily developed in the Lower and Middle Devonian sections F6 to F2 in the wells studied (Fig. 2). Middle Devonian coals occur and have been studied in several countries, including Canada, China Russia, Spain, United Kingdom and United States (Kennedy et al., 2013). Devonian coals are of interest because they represent some of the earliest coals formed on Earth, shortly following the colonization of terrestrial areas by land plants. Their compositions vary but some, such as the Middle Devonian coals of China tend to be thin, discontinuous, and rich in liptinite, cutinite and microsporinite (Dai et al., 2006). Hence, the presence of thick Lower and Middle Devonian coals in North Africa is worthy of further investigation.

In the short term, Algeria and much of the rest of North Africa has sufficient oil and gas resources in conventional reservoirs to sustain exports and in most cases meet domestic energy demand. However, in the medium term, as conventional reservoirs deplete, replacing gas resources will become more challenging, particularly for local consumption in isolated areas. As reservoirs deplete many existing wells are shutin and ultimately plugged and abandoned. In depleted fields, where multiple existing well bores penetrate thick coal seams at depths between about 1,500 to 4,000 meters, such as the Oudoume field in Algeria, there is the potential to convert the redundant wells into coal seam gas producing wells, which is worthy of evaluation. However, there would likely be several technical downhole challenges to overcome in these cased wellbores for this to be achieved. Re-use or sidetracking from existing wells could be commercially attractive as it eliminates at least some drilling costs and gas production from coals could be tied into existing production infrastructure. However, as revealed by this study the development and thickness of the Devonian coal seams can vary substantially over short distances. Indeed, the subsurface distribution of Devonian coals in Algeria is not yet well studied or understood. The future commercial potential justifies studies that better delineate the spatial distribution and thickness variations of Devonian coals across Algeria and surrounding parts of North Africa.

\section{Coalbed methane log analysis}

Provided good quality density, acoustic and neutron well 


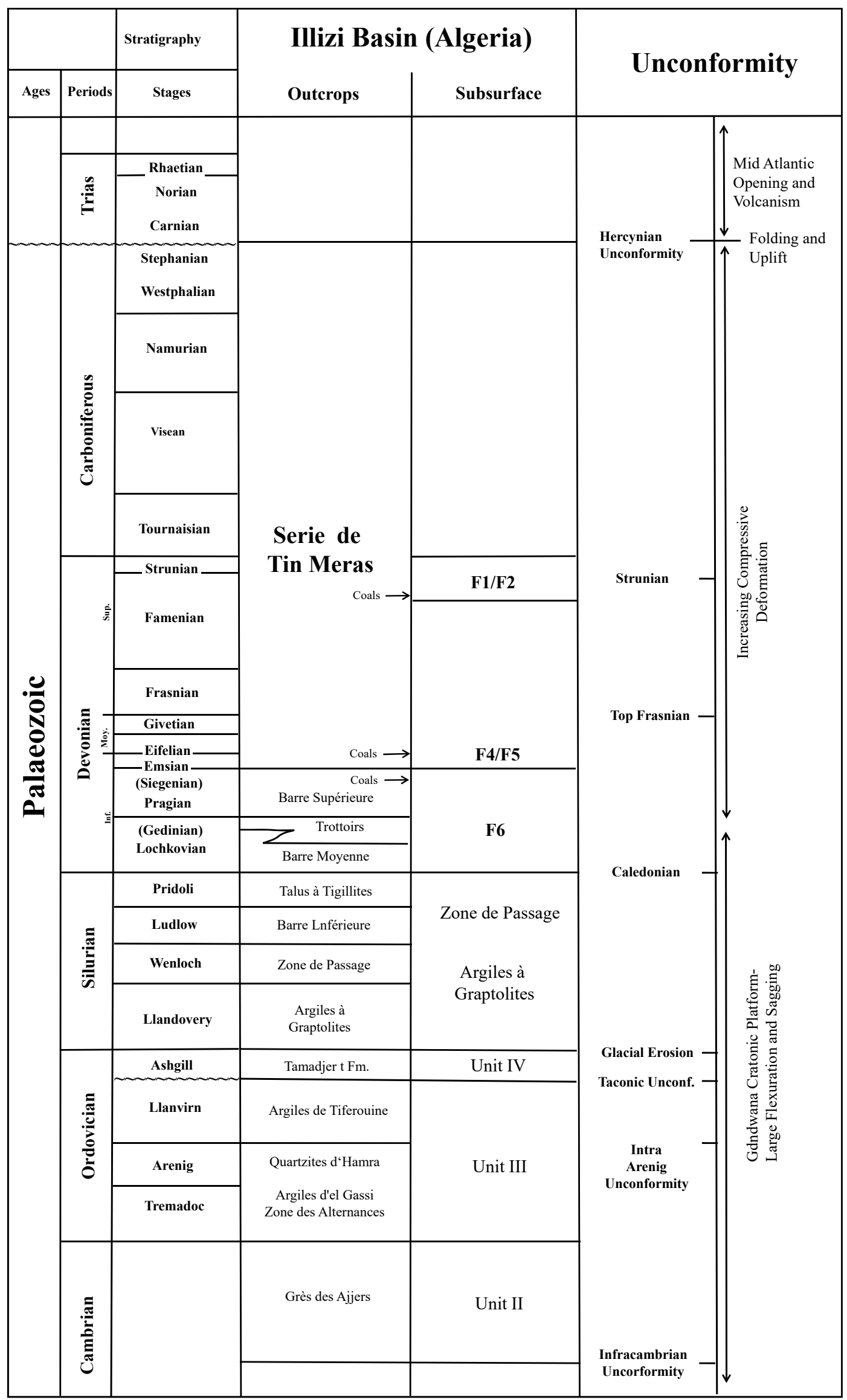

Fig. 2. Stratigraphic column representing the geologic formations and events characterizing the Illizi Basin, Algeria. Modified after Eschard et al. (2010). 
Table 1. Generic coal type identification based on wireline log responses (Mullen, 1989a (USA); Pan and Huang, 1998 (China); Deng et al., 2013 (China)).

\begin{tabular}{lllll}
\hline Coal Rank & $\begin{array}{l}\text { Matrix Density }\left(^{*}\right) \\
\rho_{m}\left(\mathrm{~g} / \mathrm{cm}^{3}\right)\end{array}$ & $\begin{array}{l}\text { Bulk Density } \\
\rho_{b}\left(\mathrm{~g} / \mathrm{cm}^{3}\right)\end{array}$ & $\begin{array}{l}\text { Acoustic Travel Time } \\
\text { Dt }(\mu \mathrm{s} / \mathrm{ft})\end{array}$ & $\begin{array}{l}\text { Neutron Porosity } \\
\text { Nphi }(\mathrm{v} / \mathrm{v})\end{array}$ \\
\hline Lignite & 1.1 & $0.5-1.22$ & $140-180$ & $0.45-0.55$ \\
Immature Bituminous & 1.25 & $1.22-2.00$ & $110-140$ & $0.55-0.60$ \\
Mature Bituminous & 1.35 & $1.22-2.00$ & $95-110$ & $>0.60$ \\
Anthracitet & 1.5 & $1.3-1.9$ & $80-90$ & $0.35-0.45$ \\
\hline
\end{tabular}

$(*)$ Note: The relationship between coal rank and coal density is complex as coal density is influenced by both organic and inorganic constituents. The matrix densities provided here are approximate but consistent with the relationships between coal density and coal rank used in other studies (Zhao et al., 2015 (China); Huang et al., 2018 (China)).

$\log$ data is available, which typically requires good borehole conditions during the logging runs, it is possible to determine the volumetric key compositional components of coal seams (ash, fixed carbon, moisture and volatiles). It is also possible to calculate with reasonable accuracy gas content (volume per unit mass of coal) and the volume of gas initially in place (GIIP) and to make estimates of potent gas productivity.

The baseline-value assumptions (Mullen, 1989a; Pan and Huang, 1998; Deng et al., 2013) for the log curves with respect to screening for coal are:

Maximum coal density $\left(\rho_{\text {bmax }}\right)=2.0 \mathrm{~g} / \mathrm{cm}^{3}$ (This value is preferred for screening purposes to $1.75 \mathrm{~g} / \mathrm{cm}^{3}$ as a few coals observed in China have densities above $1.8 \mathrm{~g} / \mathrm{cm}^{3}$, for example Deng et al. (2013)).

Minimum coal neutron porosity $\left(N p h i_{\min }\right)=0.35 \mathrm{v} / \mathrm{v}$

Minimum coal acoustic travel time $\left(D t_{\min }\right)=95 \mu \mathrm{s} / \mathrm{ft}$ $(311.7 \mu \mathrm{s} / \mathrm{m})$

Minimum coal formation resistivity $\left(R t_{\min }\right)=10 \Omega \mathrm{m} \cdot \mathrm{m}$,

Wireline $\log$ screening techniques initially identify the presence of coal seams by evaluating the log curve dataset for the distinctive combined log responses of coals, i.e., $R t>$ $10.0 \Omega \mathrm{m} \cdot \mathrm{m}, \rho_{b}<2.0 \mathrm{~g} / \mathrm{cm}^{3}, D t>95 \mu \mathrm{s} / \mathrm{ft}$ and $N p h i>0.35$.

The generic type of coal present can be distinguished (Table 1) based on four well-log inputs:

- Apparent clean coal (volume of ash $=0$ )matrix density $\left(\rho_{m}\right)$

- coal bulk density $\rho_{b}\left(\mathrm{~g} / \mathrm{cm}^{3}\right)$

- coal neutron porosity $N p h i$ (v/v, limestone units)

- coal acoustic travel time $D t(\mu \mathrm{s} / \mathrm{ft})$

The apparent clean coal (volume of ash $=0$ ) matrix density $\left(\rho_{m}\right)$ is a key metric to establish for reliable quantitative log analysis of coals. If laboratory analysis of coal core samples is available then $\rho_{m}$ for coal can be approximately calculated (Eq. (1); see note to Table 1) from the volumetric coal components: lignite $(\mathrm{v} / \mathrm{v})$; bituminous coal $(\mathrm{v} / \mathrm{v})$; and anthracite $(\mathrm{v} / \mathrm{v})$.

$$
\rho_{m}=1.1 V_{L}+1.3 V_{B}+1.5 V_{A}
$$

Log data cross plots can be used to establish $\rho_{m}$ where good quality raw $\log$ data $\left(\rho_{b}, N p h i\right.$ and $\left.D t\right)$ is available. However, this is not always possible for the following reasons:

- Some borehole do not have log data suites that include Nphi.

- Older wireline density tools (e.g., FDC-type) are unreliable at readings of $\rho_{b}<2.0 \mathrm{~g} / \mathrm{cm}^{3}$.
- Poor hole conditions due to washouts in the coal sections making wireline log readings unreliable.

An empirical relationship useful for determining the apparent matrix density for coal $\left(A \rho_{\text {matrix }}\right)$ is provided in Eqs. (2) and (3). It uses just $N p h i$ and $\rho_{b}$ data with Eq. (2) determining apparent phi $\left(p h i_{a}\right)$ as an intermediate step.

$$
\begin{gathered}
P h i_{a}=0.5\left(N p h i+\frac{\rho_{b}-2.71}{1.71}\right) \\
A \rho_{m}=\frac{\rho_{b}-P h i_{a}}{1.0-P h i_{a}}
\end{gathered}
$$

Based on $\rho_{b}, N p h i$ and $D t$ data listed in Table $1, A \rho_{m}$ is $1.3 \mathrm{~g} / \mathrm{cm}^{3}$ for lignite, $2.0 \mathrm{~g} / \mathrm{cm}^{3}$ for bituminous coal and 2.1 $\mathrm{g} / \mathrm{cm}^{3}$ for anthracite.

The volumetric coal components can be calculated using Eqs. (4)-(7) from the density $\log$ data provided $\rho_{m}$ is reliably known or determined.

$$
V_{\text {Ash }}=\frac{\rho_{b}-\rho_{m}}{2.5-\rho_{m}}
$$

where $V_{A s h}$ refers to the volume of ash. $0<=V_{A s h}<=0.40$ constraints are typically applied to avoid calculating a negative value for $V_{M}$.

$$
V_{F}=0.512-0.512 V_{A s h}
$$

where $V_{F}$ refers to the volume of fixed carbon in the coal.

$$
V_{M}=0.0461-0.1 V_{A s h}
$$

where $V_{M}$ refers to the volume of moisture in the coal.

$$
V_{V}=1.0-V_{A s h}-V_{F}-V_{M}
$$

\section{Determination of gas content of coal from log analysis}

There are several empirical equations applied in various basins to estimate the sorbed natural gas volumes in coals $(G c)$ in standard cubic feet per ton of coal (scf/ton). The Kim equation, Mavor, Close and McBanner equation and the Mullen equation are the most frequently adopted (Crain's Petrophysical Handbook, 2020). With most of the CBM equations used today based on the Kim equation or modification of it. 
The Kim equation (Kim, 1973) is calculated using Eqs. (8)-(10):

$$
G c_{\text {Kim }}=75\left(1-V_{m}-V_{a s h}\right)\left(K o P_{f}^{N o}-b T_{f}\right)
$$

where:

$$
\begin{gathered}
k o=5.6+0.8 \frac{V_{F}}{V_{M}} \\
n o=0.39-0.1 \frac{V_{F}}{V_{M}}
\end{gathered}
$$

$b=0.14$

$P_{f}=$ formation pressure (atmospheres)

$T_{f}=$ Temperature in $\left({ }^{\circ} \mathrm{C}\right)$

Modifications to the calculated gas volume are also required to express them in dry terms.

$V_{w}=$ gas volume in moist coal

$V_{d}=$ gas volume in dry coal

$V_{w} / V_{d}=0.75$

A modified Kim equation (Susanto et al., 2018) estimates the formation pressure and temperature using the depth and depth-related gradients for temperature and pressure using Eq. (11).

$$
\begin{aligned}
G c_{\text {Kimm }}= & 75\left(1-V_{M}-V_{\text {ash }}\right) \text { Ko }\left(\frac{K G 7 h}{100}\right)^{N o} \\
& -75\left(1-V_{M}-V_{a s h}\right)\left(\frac{b K G 8 h}{100}+K G 9\right)
\end{aligned}
$$

where:

$h=$ depth in meters

$K G 7=$ prevailing pressure gradient (atm per 100 meters) ters)

$K G 8=$ prevailing temperature gradient $\left({ }^{\circ} \mathrm{C}\right.$ per 100 me-

$K G 9=$ prevailing surface temperature $\left({ }^{\circ} \mathrm{C}\right)$

The simpler Mullen equation (Mullen, 1989b) was developed based on empirical data from the San Juan basin (United States) and establishes $G c$ using only bulk density $\left(\rho_{b}\right) \log$ data using Eq. (12).

$$
G c_{\text {Mullen }}=1053-542 \rho_{b}
$$

The Mavor, Close and McBaner equation (Mavor et al., 1990) establishes $G c$ using only $V_{a s h}$ and $V_{m}$ as expressed by Eq. (13).

$$
G c_{\text {Mavoretal }}=601.4-\frac{751.8 V_{a s h}}{1.0-V_{m}}
$$

The Kim formula does have some limitations to its application:

- It does not consider gas saturation and, as many coals are undersaturated, gas saturation can vary substantially from coal seam to coal seam.

- It does not consider coal compositional impacts on gas concentrations

- The original Kim formula was developed for the bituminous coals of (Pennsylvania, USA) meaning that it may not work well for different ranks of coal in different geological settings.

It is the modified Kim equation that is used here to analyze the potential gas contents of the Illizi Basin Devonian coals, because it takes into account pressure and temperature gradients as well as the volumetric coal components.

\section{Results}

\subsection{Coal characterization in the Illizi Basin}

The five Illizi Basin wells were evaluated using the Petrolog petrophysical package (Petrolog, 2019). The challenge for coal-related petrophysical analysis is the absence of neutron and density logs in all but one of the wells studied (Table 2). Only the In-Houdet-101 well has complete neutron and density logs across the Devonian coal zones. This facilitates the approximation of the volumetric coal components $\left(V_{\text {Ash }}=0.1667 ; V_{F}=0.4308 ; V_{M}=0.0294 ; V_{V}=0.3731\right)$ for that well. Although these are well-log-based approximations, in the absence of detailed coal sample analysis this are used as best estimates for this study. Those components are then applied by the Petrolog petrophysical software to determine the modified Kim gas concentration $\left(G c_{\text {Kimm }}\right)$ for each well using Eq. (11).

The basic well logging suite gamma ray (GR), acoustic

\begin{tabular}{|c|c|c|c|c|c|c|c|c|}
\hline Well & $\begin{array}{l}\text { Resistivity } \\
\text { RT }\end{array}$ & $\begin{array}{l}\text { Spontaneous Potential } \\
\text { SP }\end{array}$ & $\begin{array}{l}\text { Temperature } \\
\mathrm{T}\end{array}$ & $\begin{array}{l}\text { Sonic Travel Time } \\
\text { DT }\end{array}$ & $\begin{array}{l}\text { Gamma Ray } \\
\text { GR }\end{array}$ & $\begin{array}{l}\text { Caliper } \\
\text { Cal }\end{array}$ & $\begin{array}{l}\text { Neutron } \\
\text { Neut }\end{array}$ & $\begin{array}{l}\text { Density } \\
\mathrm{Pb}\end{array}$ \\
\hline In-Houdet & Yes & Yes & Yes & Yes & Yes & Yes & Yes & Yes \\
\hline OIT & Yes & No & No & Yes & Yes & Yes & No & No \\
\hline $\mathrm{OU}$ & Yes & Yes & No & Yes & Yes & No & Yes & No \\
\hline Sedoukane & Yes & No & No & Yes & Yes & No & No & No \\
\hline Tin Zemane & No & Yes & No & Yes & Yes & No & No & No \\
\hline
\end{tabular}
travel time (DT) and deep resistivity (RT) (Table 2) are available for the four wells that penetrate Devonian coals. Table 3 lists the ranges of those log values, the depths for the coal seams penetrated and the range of calculated $G c_{\text {Kimm }}$ values for the five wells evaluated.

Table 2. Availability of specific well log data in each of the Illizi Basin wells evaluated. 
Table 3. Basic well log characterization of Devonian coal seams drilled in the Illizi Basin. GR = gamma ray; DT = acoustic travel time; RT = deep resistivity; $G c_{\text {Kimm }}=$ Kim gas concentration calculated with the Kim equation.

\begin{tabular}{|c|c|c|c|c|c|c|c|c|c|c|}
\hline Well & $\begin{array}{l}\text { Depth } \\
\text { Min } \\
\text { Meters }\end{array}$ & $\begin{array}{l}\text { Depth } \\
\text { Max } \\
\text { Meters }\end{array}$ & $\begin{array}{l}\text { GR } \\
\text { Min } \\
\text { API Units }\end{array}$ & $\begin{array}{l}\text { GR } \\
\text { Max } \\
\text { API Units }\end{array}$ & $\begin{array}{l}\text { DT } \\
\text { Min } \\
\mu \mathrm{ft} / \mathrm{s}\end{array}$ & $\begin{array}{l}\text { DT } \\
\mathrm{Max} \\
\mu \mathrm{ft} / \mathrm{s}\end{array}$ & $\begin{array}{l}\text { RT } \\
\text { Min } \\
\text { Ohm.m }\end{array}$ & $\begin{array}{l}\text { RT } \\
\text { Max } \\
\text { Ohm.m }\end{array}$ & $\begin{array}{l}\mathrm{Gc}_{\text {Kimm }} \\
\text { Min } \\
\text { scf/ton }\end{array}$ & $\begin{array}{l}\mathrm{Gc}_{\text {Kimm }} \\
\mathrm{Max} \\
\text { scf/ton }\end{array}$ \\
\hline In-Houdet & 2399.39 & 2434.13 & 9.11 & 10.69 & 100.03 & 130.11 & 23.71 & 257.74 & 71.04 & 71.99 \\
\hline OU & 2980.03 & 3779.52 & 6.43 & 44.01 & 100.02 & 136.47 & 18.48 & 279.42 & 74.66 & 77.77 \\
\hline Sedoukane & 2816.05 & 2834.34 & 107.11 & 159.61 & 100.02 & 103.65 & 31.99 & 90.51 & 73.91 & 73.99 \\
\hline
\end{tabular}

Table 4. Summary of coal seams identified by well logs in five wells from the Illizi Basin.

\begin{tabular}{|c|c|c|c|c|c|}
\hline \multirow{2}{*}{ Well } & \multirow{2}{*}{ Formation } & \multicolumn{2}{|c|}{ Cumulative Coal Thickness } & \multicolumn{2}{|c|}{ Thickest Individual Coal Seam } \\
\hline & & (feet) & (meters) & (feet) & (meters) \\
\hline \multirow[t]{2}{*}{ In-Houdet } & Devonian F2 & 31.5 & 9.6 & 7.5 & 2.3 \\
\hline & Devonian shaly sequence above F6 & 26 & 7.9 & 11 & 3.4 \\
\hline \multirow[t]{3}{*}{ OIT } & Devonian F6M1 & 40.5 & 12.3 & 18 & 5.5 \\
\hline & Total Coal Detected & 66.5 & 20.3 & & \\
\hline & Devonian shaly sequence above F6 & 27.5 & 8.4 & 5.5 & 1.7 \\
\hline \multirow[t]{2}{*}{ Oudoume OU } & Devonian F6M1 & 67.5 & 20.6 & 53.3 & 16.2 \\
\hline & Total Coal Detected & 95 & 29 & & \\
\hline \multirow[t]{2}{*}{ Sedoukane } & Devonian shaly sequence above F6 & 6 & 1.8 & 4 & 1.2 \\
\hline & Serie Tin Meras (Carboniferous) & 9.5 & 2.9 & 1.5 & 0.5 \\
\hline \multirow[t]{2}{*}{ Tin Zemane } & Ordovician Unit IV-2/1 & 2 & 0.6 & 1.5 & 0.5 \\
\hline & Total Coal Detected & 11.5 & 3.5 & & \\
\hline
\end{tabular}

As well as characterizing the Illizi Basin Devonian coal seams a further objective of this study is to determine whether machine learning can be used with the basic well-log data available (i.e., GR, DT and RT) to predict $G_{\text {cKimm }}$ with accuracy.

Petrophysical evaluation identifies a significant number of individual coal seams in the five wells studied. The cumulative thickness, stratigraphic location and the thickest single coal seam in each well is summarized in Table 4.

The petrophysical characterization of the coal seams identified in each of these wells is illustrated in Figs. 3-9.

It is apparent from Table 4 and Figs. 3-9 that the best development of Devonian coals is in wells OU (20 m) and OIT $(29 \mathrm{~m})$ in the central part of the Illizi Basin with these coals thinning to the west ( $\sim 10 \mathrm{~m}$ in In-Houdet) and gradually disappearing to the east and Northeast $(1 \mathrm{~m}$ in Sedoukane and $0 \mathrm{~m}$ in Tin Zemane). Although the five wells studied are spread over a wide area (Fig. 1), The data suggests that there is a north-south accumulation of thick Devonian coal seams with CBM potential extending in a trend passing through the Oudoume field and at least as far south as the OIT well. There are minor traces of younger (Devonian or Carboniferous) "coals" and some Ordovician coal traces in well Tin Zemane . Although these traces are screened as "coals" they are more likely to be organic-rich marine bands as true "coals" are typically considered to originate from land plants from the Devonian period onwards. However, there are no coals in the Devonian F2 to F6 stratigraphic sequences in that well where most of the Devonian coals are located in the other four wells, indicating the main Devonian coals do not extend that far to the northeast. Studies of additional wells are required to confirm the presence and extent of the Devonian coals identified in the Illizi Basin.

\subsection{Multi-layer perceptron model applied to predict coal seam gas concentration from basic well-log data}

A multi-layer perceptron (MLP) machine learning model (see Appendix A for details) with one hidden layer and four nodes is applied to relate well-log data to coal seam gas concentration estimates. The MLP model for the Devonian coals of the Illizi Basin consists of four input variables (depth in meters, GR, DT and RT log values) with the calculated $G c_{\text {Kimm }}$ value as the dependent variable. The entire dataset of coal intervals evaluated consists of 382 data records from the four wells with Devonian coals detected:

In-Houdet-101 has 63 coal data records 


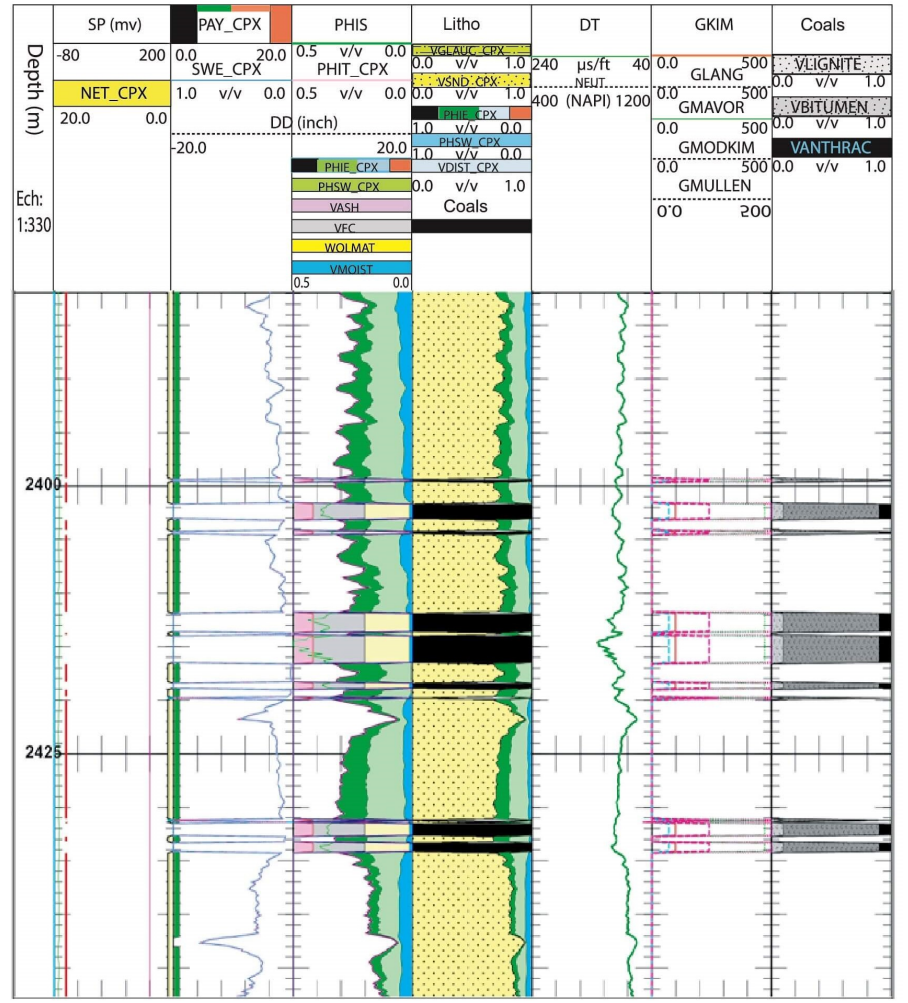

Fig. 3. Coal seams present in well In-Houdet within the predominantly sandy Devonian F2 unit. See the Abbreviations section for the acronyms used in the heading of this composite well log.

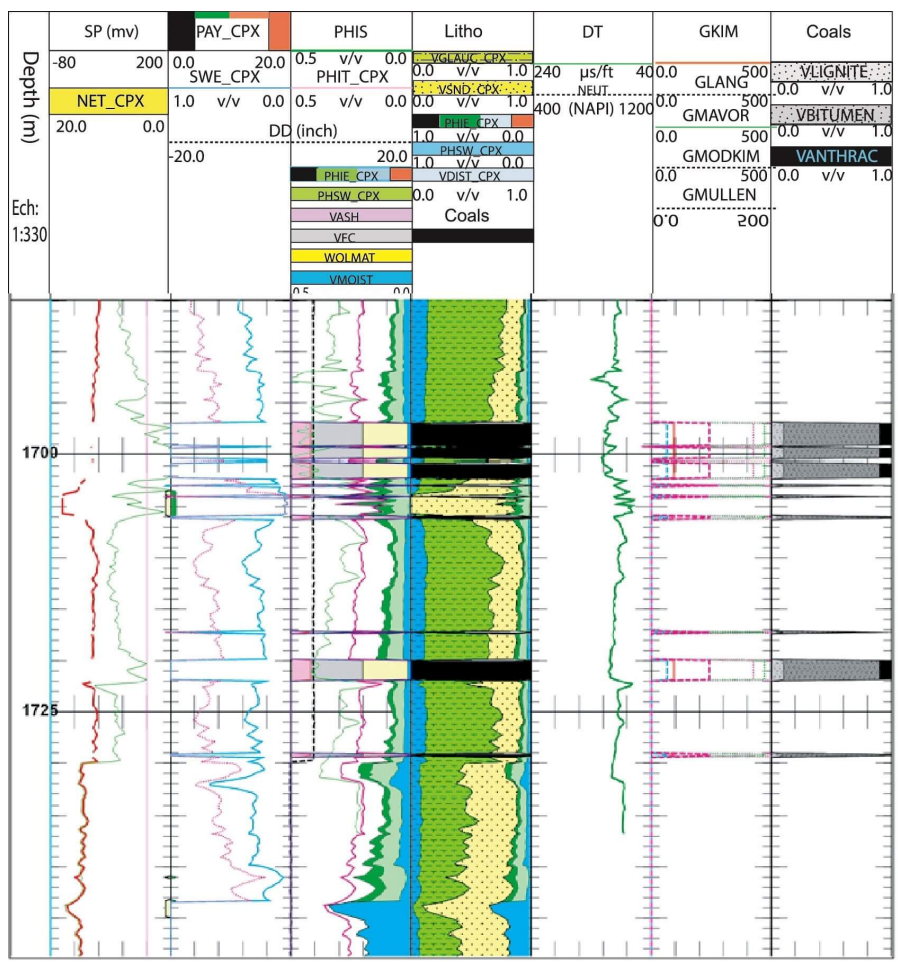

Fig. 4. Coal seams present in well OIT (Zone 1) within the Devonian shaly sequence above zone F6. See the Abbreviations section for the acronyms used in the heading of this composite well log. 


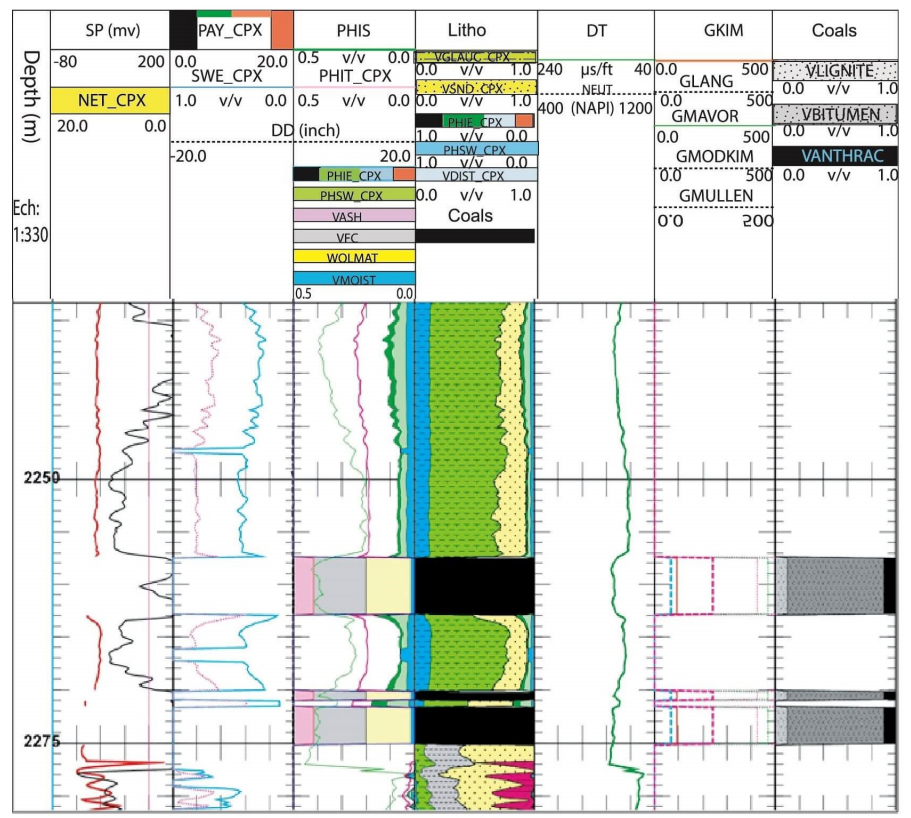

Fig. 5. Coal seams present in well OIT (Zone 2) within the predominantly shaly Devonian F6 M1 unit. See the Abbreviations section for the acronyms used in the heading of this composite well log.

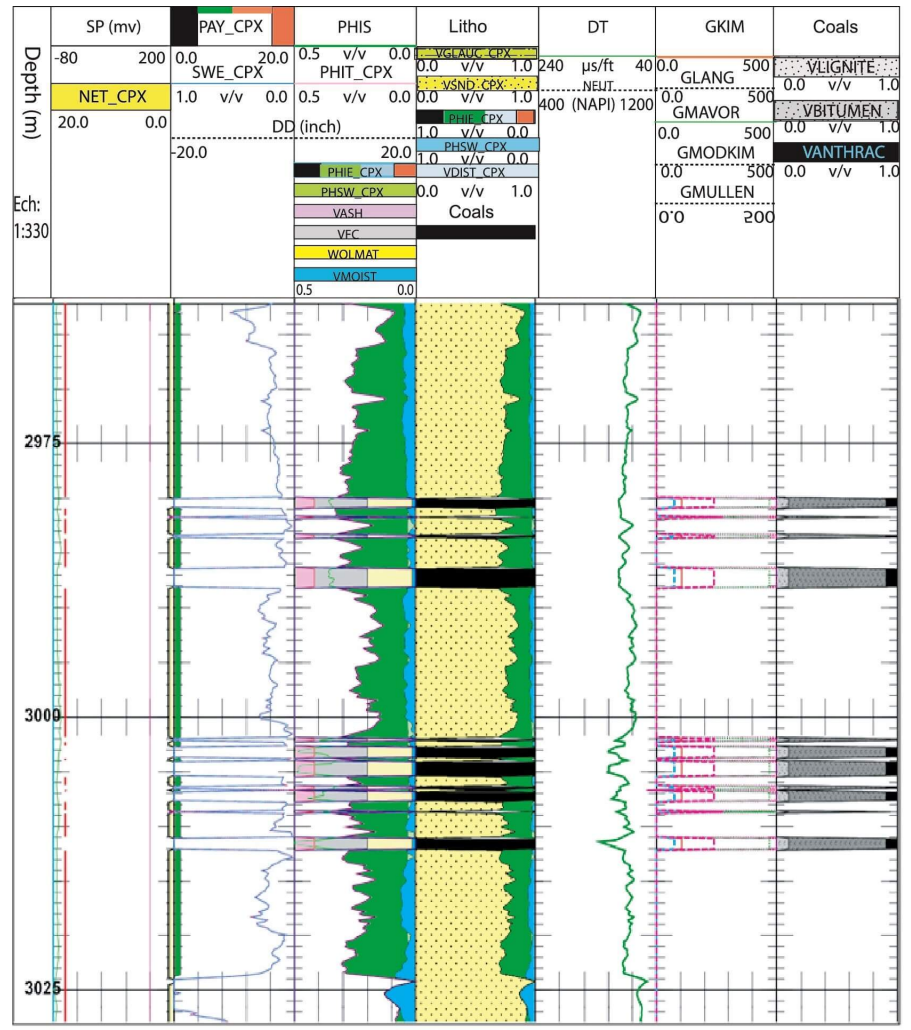

Fig. 6. Coal seams present in well OU (Zone 1) within the Devonian shaly sequence above zone F6. See the Abbreviations section for the acronyms used in the heading of this composite well log. 


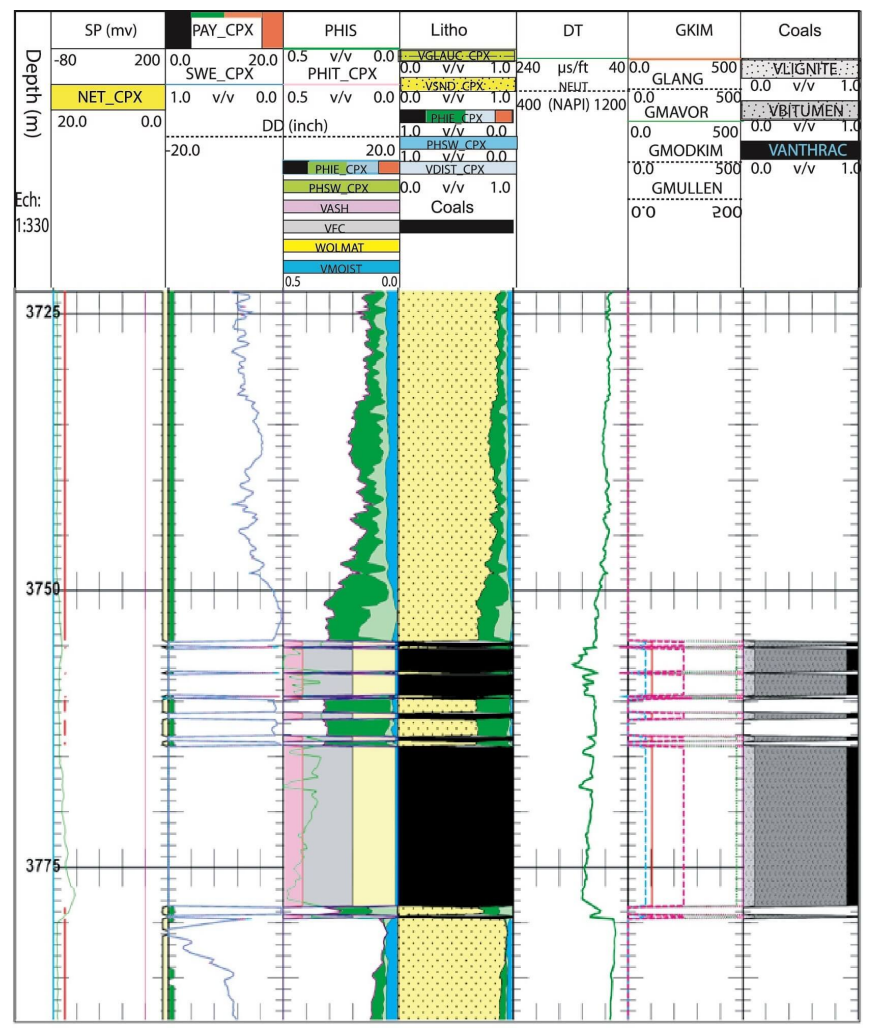

Fig. 7. Coal seams present in well OU (Zone 2) within the predominantly sandy Devonian F6M1 unit. See the Abbreviations section for the acronyms used in the heading of this composite well log.

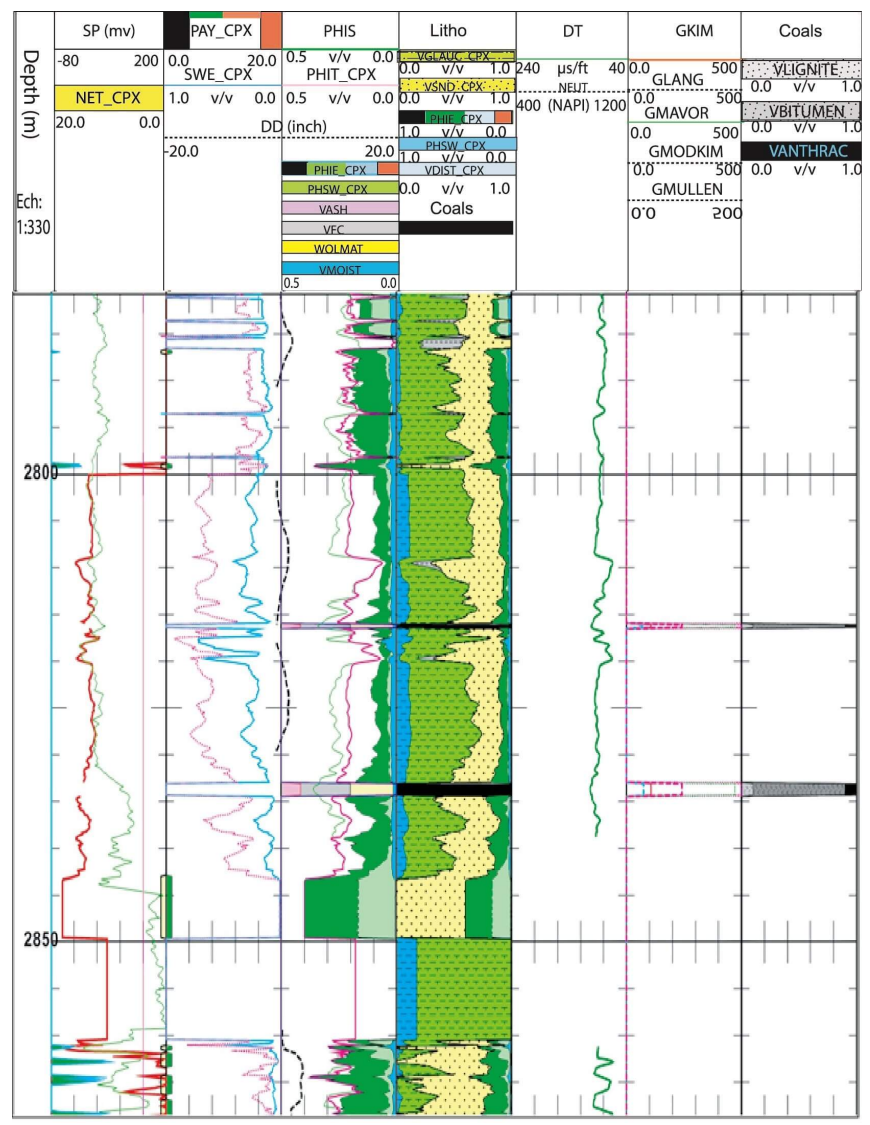

Fig. 8. Two thin isolated coal seams present in well Sedoukane (SED) within the Devonian shaly sequence above zone F6. See the Abbreviations section for the acronyms used in the heading of this composite well log. 


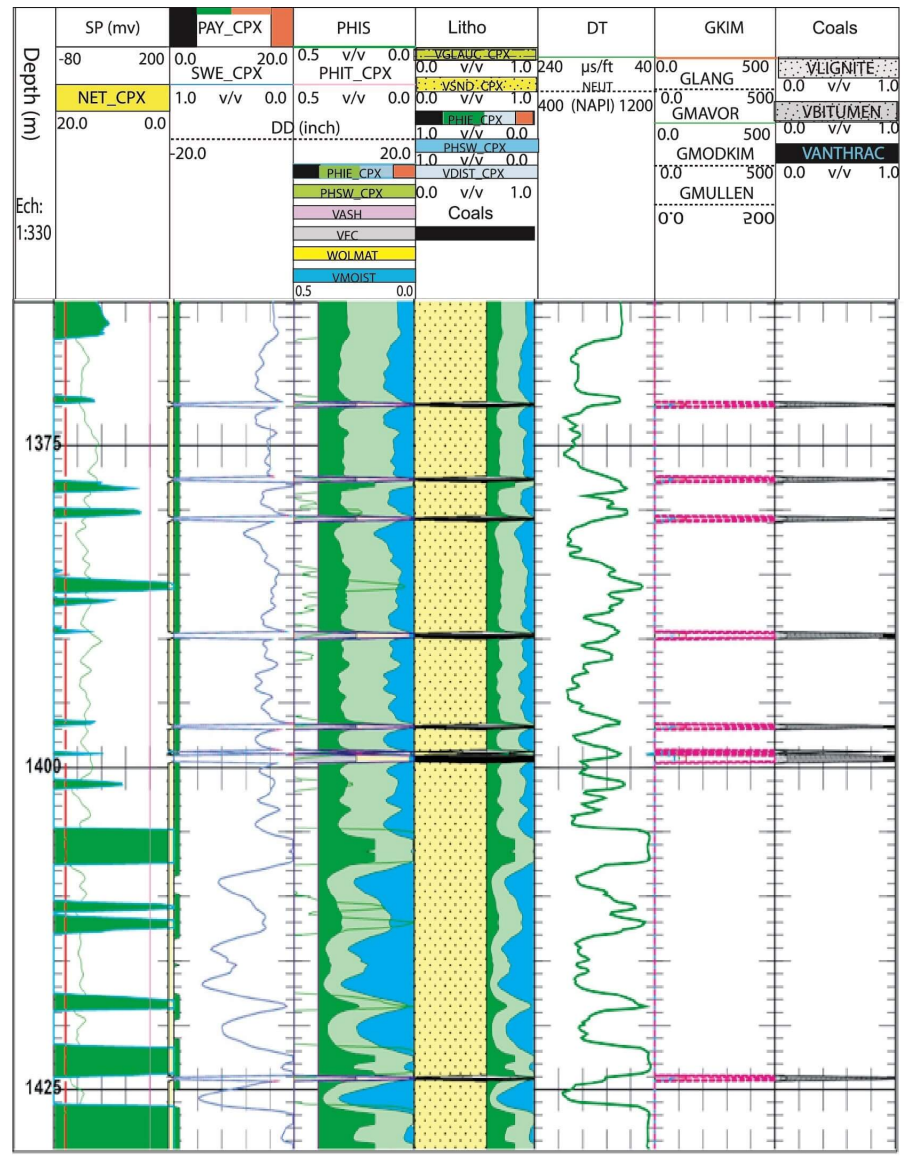

Fig. 9. Thin coal seams present in well Tin Zemane (TZM) within the Serie Tin Meras (Devonian or Carboniferous?) above Devonian F2 unit. See the Abbreviations section for the acronyms used in the heading of this composite well log.

Table 5. Weights and biases for the trained coal $\left(G c_{\text {Kimm }}\right)$ MLP machine-learning model.

\begin{tabular}{|c|c|c|c|c|c|}
\hline \multicolumn{6}{|c|}{ Weights and Biases for Trained MLP Model to Match Estimated $G c_{\text {Kimm }}$ (scf/ton) } \\
\hline $\mathrm{J}=4$ & Node 1 & Node 2 & Node 3 & Node 4 & \\
\hline \multicolumn{6}{|l|}{ Input to Hidden layer: } \\
\hline $\operatorname{Bias}\left(B_{j}\right)$ & 0.167304635118786 & 0.270751983103359 & -0.470070606568217 & 0.324542869963393 & \\
\hline Weight $\left(W_{1 J}\right)$ & 0.503664175713665 & -1.33494094674571 & -0.0705297471761705 & 0.77338499662636 & (Depth) \\
\hline Weight $\left(W_{2 J}\right)$ & 0.0049582530392568 & 0.163904172746696 & 0.308998821485765 & -0.44044679103857 & (GR) \\
\hline Weight $\left(W_{3 J}\right)$ & -0.173792725522035 & 0.22109228700796 & 0.286376239844426 & 0.459362821133492 & (DT) \\
\hline Weight $\left(W_{4 J}\right)$ & -0.184588738450031 & 0.180234563255466 & -0.126799090116702 & -0.127088398023484 & (RT) \\
\hline Hidden to Output layer: & & & & & $\operatorname{Bias}\left(B_{k}\right)$ \\
\hline Weights & 0.558862254950964 & -1.34455102951834 & 0.004416265406478 & 0.692837269822662 & 0.135823020787241 \\
\hline
\end{tabular}

OIT-1 has 117 coal data records

OU-101 has 190 coal data records

Sedoukane-1 has 12 coal data records

The 307 coal data records from wells OIT and OU were used to train and validate the MLP model. Once trained the MLP model was applied to predict the $G c_{\text {Kimm }}$ values the 75 data records from wells In-Houdet and Sedoukane. For MLP training the 307 coal data records from wells OIT- 1 and OU101 were randomly divided into $269(\sim 88 \%)$ allocated to the training subset and $38(\sim 12 \%)$ data records allocated to the validation subset. The four-node / 1-hidden layer MLP trained model achieved estimated $G c_{\text {Kimm }}$ replication for the training subset with MSE $=0.000995$ (normalized data) and $\mathrm{R}^{2}$ $=0.9830$. The validation subset data-record matches showed comparable results MSE $=0.000942$ (normalized data) and $\mathrm{R}^{2}=0.9866$ providing confidence in the optimized solution derived. Fig. 10 illustrates the trained MLP solution applied to all 307 data records of the training and validation subsets with $G c_{\text {Kimm }}$ expressed in actual units (not normalized terms).

The weights and biases of the trained MLP solution (Table 5) are applied to the testing subset consisting of 75 Devonian coal data records from wells In-Houdet-1 and Sedoukane-1 


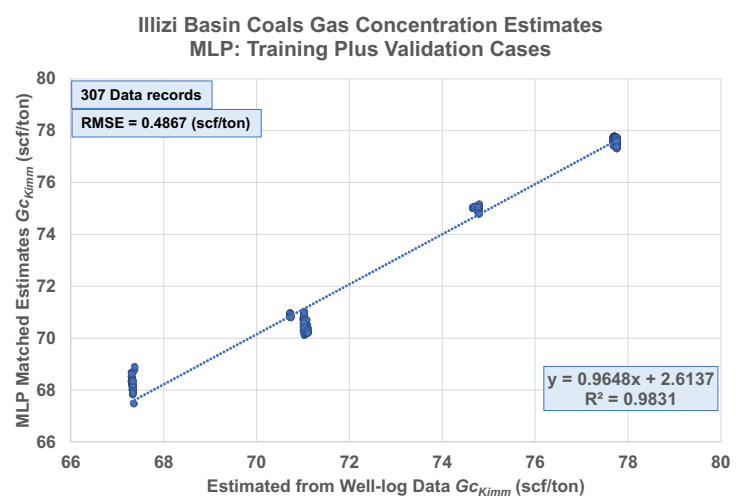

Fig. 10. Matches for dependent variable $\left(G c_{\text {Kimm }}\right)$ for all data records in the training and validation subsets applying the trained MLP solution.

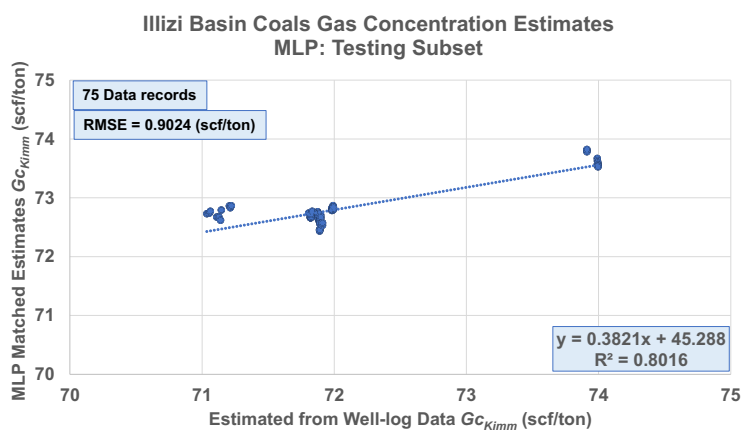

Fig. 11. Matches for dependent variable $\left(G c_{\text {Kimm }}\right)$ for all data records in the training and validation subsets applying the trained MLP solution.

with a comparison of predicted versus calculated $G c_{K i m m}$ illustrated in Fig. 11, with $G c_{\text {Kimm }}$ expressed in actual units (not normalized terms).

The root mean square error (RMSE) achieved for the dependent-variable matches of the testing subset is less than 1 scf/ton, which suggests that the MLP model offers sufficient accuracy to estimate gas concentration in the Devonian coals from basic well log data (GR, DT, RT) and depth.

\subsection{Plans for future refinements to the MLP model}

The results of the MLP model developed and evaluated by this study are an encouraging outcome that could be used to evaluate the Devonian coals penetrated by other well bores with limited well $\log$ information. However, confidence in the MLP model could be increased by adding additional data records from other Illizi Basin wells that have penetrated Devonian coals. This MLP machine-learning petrophysical model would also be further refined and substantially improved by combining it with coal sample laboratory analysis and experiments to provide more extensive coal component analysis. Future work is planned to do this, and to evaluate a wider range of well-log variables in conjunction with other machine learning algorithms.

\section{Discussion}

This study has described the presence of a thick, but spatially limited, areal trend of Devonian coals in the Illizi
Basin based on the study of just a five wells. Moreover, it is clear that with data from a limited suite of basic well logs, recorded in most wells drilled, those coal seams can be successfully identified and characterized in terms of their thickness and gas potential. Machine learning models can evaluate the approximate well-log data calculations to replicate their gas concentration estimates for those coal. Unfortunately, there are no other published studies that assess and characterize Devonian coals in Algeria or on a regional basis using available well-log data.

There are many other wellbores drilled in the Illizi Basin that could be used to further delineate the extent of the thick Devonian coal areal trend. Unfortunately, most of those wells have only recorded a basic suite of well log data (GR, DT and $\mathrm{RT}$ ). This suggests that there is considerable scope to conduct more extensive regional studies using basic well $\log$ data to better delineate and characterize Devonian coals and their gas production potential. The results of this study demonstrate that meaningful analysis of the potential gas concentration and thickness of the coals penetrated by those wellbore could be established from limited available well $\log$ data. This would enable a more realistic quantitative assessment of the coalbed methane potential associated with the Devonian coals of the Illizi Basin and more regionally across Algeria and North Africa.

\section{Conclusions}

The five-well petrophysical study conducted on Devonian coals in the central and northeastern portion of the Illizi Basin (Algeria) identifies the presence of a substantial but variable thickness of such coals. This study characterizes these coals with the following findings:

The Devonian coals are best developed in terms of thickness in an areal trend near to the center of the Illizi Basin in the vicinity of the Oudoume field $(29 \mathrm{~m})$. Based on just five wells, the coals appear to extend approximately north -south towards well OIT-1 $(20 \mathrm{~m})$. That trend needs to be further delineated with additional well data.

The thickest coal seams are developed in the Lower Devonian stratigraphic unit F6 with the thickest individual coal seam exceeding $16 \mathrm{~m}$ in Oudoume field.

The available petrophysical information (a basic suite of well $\operatorname{logs}$ ) is used to calculate gas content of the Devonian coals with the modified Kim equation. These calculations reveal that gas content can be provisionally estimated to vary from 67 to $77 \mathrm{scf} /$ ton.

A simple multi-layer perceptron (MLP), machine-learning model using the basic well-log data for gamma ray, sonic travel time, deep resistivity and depth is able to replicate the logbased gas content estimates calculated with the modified Kim equation to an accuracy of less than plus or minus $1 \mathrm{scf} / \mathrm{ton}$.

To be clear, as no gas-desorption tests were conducted on the coal seams logged in the five wells studied log-derived gas contents can only be considered as preliminary approximations. The "accuracy" of the machine-learning estimates is with respect to the Kim-formula calculations not the actual gas contents of the coals. The actual gas content of the coals 
will remain unknown until laboratory analysis is conducted.

The MLP model, with four nodes in a single hidden layer, offers potential to assist in further characterizations and estimations of the coalbed methane resource potential in the Devonian coal areal trend present in the central part of the Illizi Basin exploiting additional well data. The results reported justify expanding this study to include additional well data comprising well-log variables and down-hole sample analysis.

\section{Nomenclature}

The abbreviations used in the headings to Figs. 3-9 are:

$\mathrm{CPX}=$ Complex lithology interpretation

$\mathrm{SP}=$ Spontaneous potential $[\mathrm{mV}]$

SWE-CPX = Effective water saturation $[\mathrm{v} / \mathrm{v}]$

SWT-CPX $=$ Total water saturation $[\mathrm{v} / \mathrm{v}]$

PHIS $=$ Sonic porosity $[\mathrm{v} / \mathrm{v}]$

PHIE $=$ Effective porosity $[\mathrm{v} / \mathrm{v}]$

$\mathrm{PHXO}=$ Flushed zone porosity

PHSW $=$ Porosity $*$ water saturation $[\mathrm{v} / \mathrm{v}]$

$\mathrm{VASH}=$ Volume of ASH $[\mathrm{v} / \mathrm{v}]$

$\mathrm{VFC}=$ Volume of fixed carbons $[\mathrm{v} / \mathrm{v}]$

VVOLMAT $=$ Volume volatile matter $[\mathrm{v} / \mathrm{v}]$

VMOIST $=$ Volume of moisture $[\mathrm{v} / \mathrm{v}]$

VGLAUC $=$ Volume of glauconite $[\mathrm{v} / \mathrm{v}]$

VSILT $=$ Volume of silt $[\mathrm{v} / \mathrm{v}]$

VSND $=$ Volume of sand $[\mathrm{v} / \mathrm{v}]$

VHMIN $=$ Volume of heavy minerals $[\mathrm{v} / \mathrm{v}]$

VDIS = Volume of dispersed clay $[\mathrm{v} / \mathrm{v}]$

$\mathrm{DT}=$ Sonic $[\mu \mathrm{s} / \mathrm{ft}]$

NEUT $=$ Neutron [NAPI $]$

GKIM = Coalbed methane gas volume-kim equation $[\mathrm{CF} / \mathrm{T}]$

GLANG $=$ Coalbed methane gas volume-langmuir equation $[\mathrm{CF} / \mathrm{T}]$

GMAVOR = Coalbed methane gas volume-mavor, close, mcbaner equation $[\mathrm{CF} / \mathrm{T}]$

GMODKIM = Coalbed methane gas volume-modified kim equation $[\mathrm{CF} / \mathrm{T}]$

GMULLEN $=$ Coalbed methane gas volume-mullen equation $[\mathrm{CF} / \mathrm{T}]$

VLIGNITE $=$ Volume of lignite coal (from RHOMAA vs

DT crossplot) $[\mathrm{v} / \mathrm{v}]$

VBITUMEN = Volume of bituminous coal (from

RHOMCA vs DT crossplot) [v/v]

VANTHRAC $=$ Volume of anthracite coal (from RHOMCA vs DT crossplot) [v/v]

\section{Acknowledgement}

This research was supported by the Laboratory of Resources Minérals at Energétiques from University of Boumerdes and the Directorate General for Scientific Research and Technological Development (DG-RSDT) of the Ministry of Higher Education and Scientific Research of Algeria.

We express our sincere thanks to SONATRACH Company for access to the well data and for their technical support.

\section{Conflict of interest}

The authors declare no competing interest.

Open Access This article, published at Yandy Scientific Press on behalf of the Division of Porous Flow, Hubei Province Society of Rock Mechanics and Engineering, is distributed under the terms and conditions of the Creative Commons Attribution (CC BY-NC-ND) license, which permits unrestricted use, distribution, and reproduction in any medium, provided the original work is properly cited.

\section{References}

Ayers, W.B. Coalbed gas systems, resources, and production and a review of contrasting cases from the San Juan and Powder River basins. AAPG Bull. 2002, 86(11): 18531890.

Battiti，R. First-and second-order methods for learning: Between steepest descent and Newton's method. Neural Comput. 1992, 4(2): 141-166.

Beuf, S., Biju-Duval, B., De Chapal, O., et al. Les Grès du paléozoïque inférieur au Sahara: Sédimentation et discontinuités, évolution structural. Earth-Sci. Rev. 1972, 8(3): 331-333.

Bodden, R.W., Ehrlich, R. Permeability of coals and characteristic of desorption tests: Implications for coalbed methane production. Int. J. Coal Geol. 1998, 35(1-4): 333-347.

Boote, D.R.D., Clark-Lowes, D.D., Traut, M.W. Palaeozoic petroleum systems of North Africa. Geol. Soc. Lond. Spec. Publ. 1998, 132(1): 7-68.

Busch, A., Gensterblum, Y. CBM and $\mathrm{CO}_{2}-\mathrm{ECBM}$ related sorption processes in coal: A review. Int. J. Coal Geol. 2011, 87(2): 49-71.

Busch, A., Gensterblum, Y., Krooss, B.M., et al. Investigation of high-pressure selective adsorption/desorption behaviour of $\mathrm{CO}_{2}$ and $\mathrm{CH}_{4}$ on coals: An experimental study. Int. J. Coal Geol. 2006, 66(1-2): 53-68.

Bustin, R.M., Clarkson, C.R. Geological controls on coalbed methane reservoir capacity and gas content. Int. J. Coal Geol. 1998, 38(1-2): 3-26.

Clarkson, C.R., Bustin, R.M. Binary gas adsorption/desorption isotherms: Effect of moisture and coal composition upon carbon dioxide selectivity over methane. Int. J. Coal Geol. 2000, 42(4): 241-271.

Crain's Petrophysical Handbook, 2020.

Crosdale, P.J., Moore, T.A., Mares, T.E. Influence of moisture content and temperature on methane adsorption isotherm analysis for coals from a low-rank, biogenically-sourced gas reservoir. Int. J. Coal Geol. 2008, 76(1-2): 166-174.

Dai, S., Han, D., Chou, C. Petrography and geochemistry of the Middle Devonian coal from Luquan, Yunnan Province, China. Fuel 2006, 85(4): 456-464.

Deng, S., Hu, Y., Chen, D., et al. Integrated petrophysical log evaluation for coalbed methane in the Hancheng area, China. J. Geophys. Eng. 2013, 10(3): 035009.

Diamond, W.P., Schatzel, S.J. Measuring the gas content of coal: A review. Int. J. Coal Geol. 1998, 35(1-4): 311-331.

Energy Information Authority of the United States Department of Energy (EIA). Natural gas: Coalbed methane reserves 
and production statistics. Energy Information Authority 2020.

Eschard, R., Abdallah, H., Braik, F., et al. The Lower Paleozoic succession in the Tassili outcrops, Algeria: Sedimentology and sequence stratigraphy. First Break 2005, 23(10): 27-36.

Eschard, R., Braik, F., Bekkouche, D., et al. Palaeohighs: Their influence on the North African Palaeozoic petroleum systems. Geol. Soc. London 2010, 7(1): 707-724.

Fausett, L.V. Fundamentals of Neural Networks: Architectures, Algorithms and Applications. NJ, USA, Prentice-Hall, Inc., 1994.

Fekirine, B., Abdallah, H. Palaeozoic lithofacies correlatives and sequence stratigraphy of the Saharan Platform, Algeria. Geol. Soc. Lond. Spec. Publ. 1998, 132(1): 97-108.

Flores, R.M. Coalbed methane: From hazard to resource. Int. J. Coal Geol. 1998, 35(1-4): 3-26.

Flores, R.M. Coal and Coalbed Gas: Fueling the Future. Oxford, UK, Newnes, 2013.

Ghienne, J.F., Boumendjel, K., Paris, F., et al. The CambrianOrdovician succession in the Ougarta range (western Algeria, North Africa) and interference of the late Ordovician glaciation on the development of the lower Palaeozoic transgression on northern Gondwana. Bull. Geosci. 2007, 82(3): 183-214.

Haykin, S. Neural Networks: A Comprehensive Foundation. NJ, USA, Prentice Hall, 1994.

Hirst, J.P.P. Ordovician proglacial sediments in Algeria: Insights into the controls on hydrocarbon reservoirs in the In Amenas field, Illizi Basin. Geol. Soc. Lond. Spec. Publ. 2012, 368(1): 319-353.

Hornik, K. Approximation capabilities of multilayer feedforward networks. Neural Netw. 1991, 4(2): 251-257.

Hornik, K., Stinchcombe, M., White, H. Multilayer feedforward networks are universal approximators. Neural Netw. 1989, 2(5): 359-366.

Huang, B., Qin, Y., Zhang, W., et al. Identification of the coal structure and prediction of the fracturability in the No. 8 coal reservoir, Gujiao block, China. Energy Explor. Exploit. 2018, 36(2): 204-229.

Kennedy, K.L., Gibling, M.R., Eble, C.F., et al. Lower Devonian coaly shales of northern New Brunswick, Canada: Plant accumulations in the early stages of terrestrial colonization. J. Sediment. Res. 2013, 83(12): 1202-1215.

Kim, A.G. The Composition of Coalbed Gas. Washington, USA, Bureau of Mines, 1973.

Laxminarayana, C., Crosdale, P.J. Role of coal type and rank on methane sorption characters of Bowen Basin, Australia coals. Int. J. Coal Geol. 1999, 40(4): 309-325.

Laxminarayana, C., Crosdale, P.J. Controls on methane sorption capacity of Indian coals. AAPG Bull. 2002, 86(2): 201-212.

LeHeron, D.P., Craig, J., Etienne, J.L. Ancient glaciations and hydrocarbon accumulations in North Africa and the Middle East. Earth-Sci. Rev. 2009, 93(3-4): 47-76.
Levine, J.R. Coalification: The evolution of coal as source rock and reservoir rock for oil and gas, in SG 38: Hydrocarbons from Coal, edited by B.E. Law and D.D. Rice, American Association of Petroleum Geologists Studies in Geology, Tulsa, pp. 39-77, 1993.

Li, P., Ma, D., Zhang, J., et al. Effect of wettability on adsorption and desorption of coalbed methane: A case study from low-rank coals in the southwestern Ordos Basin, China. Ind. Eng. Chem. Res. 2018, 57(35): 1200312015.

Li, T., Wu, C., Liu, Q. Characteristics of coal fractures and the influence of coal facies on coalbed methane productivity in the South Yanchuan Block, China. J. Nat. Gas Sci. Eng. 2015, 22: 625-632.

Liu, H., Mou, J., Cheng, Y. Impact of pore structure on gas adsorption and diffusion dynamics for long-flame coal. J. Nat. Gas Sci. Eng. 2015, 22: 203-213.

Liu, J., Chen, Z., Elsworth, D., et al. Interactions of multiple processes during CBM extraction: A critical review. Int. J. Coal Geol. 2011, 87(3-4): 175-189.

Lu, W., Huang, B., Zhao, X. A review of recent research and development of the effect of hydraulic fracturing on gas adsorption and desorption in coal seams. Adsorp. Sci. Technol. 2019, 37(5-6): 509-529.

Mastalerz, M., Drobniak, A., Strąpoć, D., et al. Variations in pore characteristics in high volatile bituminous coals: Implications for coal bed gas content. Int. J. Coal Geol. 2008, 76(3): 205-216.

Mavor, M.J., Close, J.C., McBane, R.A. Formation evaluation of exploration coalbed-methane wells. SPE Form. Eval. 1994, 9(4): 285-294.

McLennan, J.D., Schafer, P.S., Pratt, T.J. A guide to determining coalbed gas content: Gas Research Institute. Top. Rep. GRI 1995, 94(396): 123.

Moore, T.A. Coalbed methane: A review. Int. J. Coal Geol. 2012, 101: 36-81.

Mullen, M.J. Log evaluation in well drilled for coalbed methane. RockyMountain Assoc. Geol. 1989a, 38: 113124.

Mullen, M.J. Coalbed Methane Resource evaluation from wireline $\operatorname{logs}$ in the northeastern San Juan Basin: A case study. Paper SPE 18946 Presented at Low Permeability Reservoirs Symposium, Denver, Colorado, USA, 6-8 March, 1989b.

Olajossy, A., Cieślik, J. Why coal bed methane (CBM) production in some basins is difficult. Energies 2019, 12(15): 2918.

Olajossy, A. Some parameters of coal methane system that cause very slow release of methane from virgin coal beds (CBM). Int. J. Min. Sci. Technol. 2017, 27(2): 321-326.

Pan, H., Huang, Z. Log interpretation model of determining coalbed coal quality parameters. Geoscience 1998, 12(3): 447-451. (in Chinese)

Pan, Z., Wood, D.A. Coalbed methane (CBM) exploration, reservoir characterisation, production, and modelling: A collection of published research (2009-2015). J. Nat. Gas Sci. Eng. 2015, 100(26): 1472-1484. 
Petrolog, Petrophysical software. 2019

Pillalamarry, M., Harpalani, S., Liu, S. Gas diffusion behavior of coal and its impact on production from coalbed methane reservoirs. Int. J. Coal Geol. 2011, 86(4): 342348.

Reddy, K.J. Coalbed Natural Gas: Energy and Environment. New York, USA, Nova Science Publishers, 2010.

Seidle, J. Fundamentals of Coalbed Methane Reservoir Engineering. Tulsa, USA, PennWell Books, 2011.

Strąpoć, D., Mastalerz, M., Dawson, K., et al. Biogeochemistry of microbial coal-bed methane. Annu. Rev. Earth Planet. Sci. 2011, 39: 617-656.
Susanto, H., Sondakh, K., Sitaresmi, R., et al. Evaluation of initial gas volume of coalbed methane using four method. J. Mech. Eng. Mechatronics 2019, 3(1): 28-39.

Tang, S., Tang, D., Tang, J., et al. Controlling factors of coalbed methane well productivity of multiple superposed coalbed methane systems: A case study on the Songhe mine field, Guizhou, China. Energy Explor. Exploit. 2017, 35(6): 665-684.

Zhao, P., Mao, Z., Jin, D., et al. Investigation on log responses of bulk density and thermal neutrons in coalbed with different ranks. J. Geophys. Eng. 2015, 12(3): 477-484. 


\section{Appendix: Multi-layer oerceptron model description}

Multi-layer Perceptrons (MLP) are artificial neural networks (ANN) that are widely used to conduct machine learning of non-linear datasets (Hornik et al., 1989; Fausett, 1994). They consist of a network of interconnections between nodes, analogous to neuron connections in a brain, is established in a series of one or more layers between input and output interfaces (Haykin, 1994). Sensitivity analysis establishes the number of nodes and hidden layers that provides the best accuracy for a specific dataset. Weight and bias values coupled with activation or transformation functions determined how values are passed from one MLP layer to another. In this study, sensitivity analysis identified one hidden layer with four nodes as the optimum MLP architecture. Further trial-and-error testing showed that a sigmoidal function applied to the hidden layer and a purelin (simple linear) activation function applied to the output layer generated the best results. A number of data records from the dataset are used to train the MLP with an additional set of data records (without replacement) used to validate it. Once trained the MLP can be applied to predict unknown data records.

Eq. (A-1) provides the mathematical determination of the value calculated at the $j^{\text {th }}$ node in the MLPNN's hidden layer.

$$
A_{j}=B_{j}+\sum_{j=1}^{m} w_{i j} X_{i}
$$

where $A_{j}$ is the weighted summed value of the $n$ input nodes; $X_{i}$ is the value at input node $i ; \mathrm{w}_{i j}$ is the weight assigned to the connection between the $i^{\text {th }}$ input node to the $j^{t h}$ (of $m$ ) hidden node; and $B_{j}$ is the distinct bias term of the $j^{\text {th }}$ node of the hidden.

The output value for the $j_{t h}$ node in the hidden layer is transformed from the value calculated in Eq. (A-1) using and activation function $f(A)$. In the model developed a sigmoidal activation function $f(A)$ is applied using Eq. (A-2) is expressed by Eq. (A-3) and is used to transform the $A_{j}$ hidden layer output values from Eq. (A-1).

$$
f(A)=\frac{1}{1+e^{-A}}
$$

The MLP's output layer value $O_{k}$ from the MLPNN is calculated with Eq. (A-3)

$$
O_{k}=\left[\sum_{j=1}^{m} w_{i k} * Y_{j}\right]+B_{k}
$$

where $Y_{j}$ is the transformed output value for the $j_{t h}$ node in the hidden layer; $w_{j k}$ is the weight between the $j_{t h}$ hidden neuron to the one output neuron, $k$; and, $B_{k}$ is the bias term associated with the single output neuron. Note that $k$ could be greater than 1 if there are more than one dependent variables. $O_{k}$ is then adjusted by a simple linear activation function (purelin) to calculate $P_{k}$, the predicted dependent variable value using Eq. (A-4).

$$
P_{k}=O_{k} 1
$$

All data input to the MLP is transformed into normalized values. Hence, the predicted values need to be denormalized to be expressed in the dependent variable units.

A back-propagation algorithm (Battiti, 1992) is applied to optimize the weights and biases as part of the training of the MLPNN model. The objective function optimized by the back-propagation algorithm is the mean squared error (MSE) of the difference between the actual and predicted dependent variable value for all data records in the subset used to train the MLP MSE is calculated with Eq. (A-5):

$$
M S E=\frac{1}{n} \sum_{i=1}^{i=n}\left(R_{i}-P_{i}\right)
$$

where $R_{i}$ is the calculated dependent variable value for a given training subset data record $i ; P_{i}$ is the predicted dependent variable value for training subset data record $i$; and, $n$ is the total number of training subset data records

Once the MLP model is trained and validated it can be applied to predict the dependent variable values in other data records for which the input variables are available. 